\title{
Migrants during CoviD-19 Pandemic: A Discursive Class Formation of Returnee Expatriates
}

\author{
K. M. Mahmudul Haque ${ }^{1} \&$ Arafatur Rahaman ${ }^{2}$ \\ ${ }^{1}$ Department of Anthropology, Jatiya Kabi Kazi Nazrul Islam University, Trisal, Mymensingh, Bangladesh \\ ${ }^{2}$ School of Business Studies, Southeast University, Bangladesh \\ anthromahmud@gmail.com, a.rahaman133@gmail.com
}

\begin{abstract}
Amidst the outbreak of the Covid-19 pandemic, migrants are the most affected parts after the Health and economy. More than half a million migrants have returned from February to May 2020 to Bangladesh. The state and society have stigmatized returnee expatriates as suspected disease carriers. Some of them are being physically assaulted and humiliated by their neighbor and society. Researchers revealed a new dimension of "Othering" discourse; where consent of hate crime formed being solely blamed for bring coronavirus and ignoring mandatory quarantine period. The government officially stigmatized them by putting quarantined seals at their hands and hoisting red flags at their homes. Interestingly, we have found the distinction of stigmatization between returnee expatriates, where returnee workers were being humiliated rather than high-skilled returnee professionals from a so-called developed country. Returnee expatriates experienced a transformation of identity. Researchers argued about the discursive formation of a class of returnee expatriates who were once highly respected and spoiled of their identity as a probable source of virus carrier. Once labeled as a remittance fighter of the economy have to transients their so-called positions, and has to prove their worthiness as a citizen of the state, after starting the pandemic, governments and their developing partners were not humane, concerned about the returnee expatriates' social discrimination, risk of unemployment, uncertainty, economic crisis, and instability. Returnee expatriates' abandonment as a suspected carrier of the COVID-19 virus by the state and society should be worked out more comprehensively to protect them from social and economic exploitation.
\end{abstract}

Keywords: Migrants; Covid-19 pandemic; Returnee expatriates; Stigmatization; Discursive formation of a class.

\section{Introduction}

Coronavirus (COVID-19) attacked the whole world in such a way that all are stuck. Abundant scientific researchers are trying to figure it out. However, the breakneck change of this invisible enemy has made the situation gauche. If we moot the virus's impingement on people's lives, then it will be a rhapsody. The impact is not the same for all. Though the virus affects equally all sorts of people, the vulnerability is not the same. Response to COVID-19 can make new susceptibility. Therefore, social scientists are highly concern about the aftershock of this pandemic. Bangladesh is persistent in its economic growth amidst global uncertainties (World Bank-2017). However, this coronavirus is hampering the stable economy and bringing forth a fundamental question of whether people should focus on life or economy. The government of Bangladesh did not stop international flights because of the upcoming economic loss. Simultaneously, the general leave of office has been recalled, and the market and other sectors have been reopened because of economic constancy. In Bangladesh's economy, one of the most influential sectors of GDP is foreign remittance. Last year 18.3 billion US dollars was sent through the banking channel (The Daily Star, 2020). However, the coronavirus affected the world economy, and that is why foreign remittance is down.

Being aware and giving high importance, to maintain the flow government declared a $2 \%$ cash incentive without inspection for sending money up to 5 thousand US dollars (The Daily Star, 2020). The crucial fact is that remittance earned around 40\% foreign exchange, the second-highest, and just after the garment sector (Daily Sun, 2020). However, the real irony is that COVID-19 reveals behind the scene our mentality. Whether we are highly concern about our garment industries' owners, we are as bitchier to foreign exchanges. Recently we shared malicious videos of a group of people who are the measureless contributor to the remittance. We shared that the returnee people from different countries are the real contributor to the coronavirus as well. By sharing a video with a caption of "indeed they fucked this country" we blamed all the foreign remittance earners of the country. People have pissed off the word "Bidesh Ferot" (returned from foreign countries or not from motherland). According to Govt., half a million returnees entered throw the airport only in January-February (BBC Bangla, 2020). All these are not workers or so-called "Probashi" (migrants). Among them, there are various kinds of people. It can be said that the coronavirus was carried by 
someone, but it cannot be said that it was carried by a worker. Anyone could be the carrier. Unfortunately, the connotation of the shared videos and captions direct that the lower class, uneducated, labor class people were the carrier of this virus. This is a gimcrack generalization. The most exciting thing is that no one raises this question against the so-called educated (living in other countries for study), higher class (doing 'good' job), wealthy persons. Having this class distinction people are stigmatizing those "Probashi"s/"Bideshi"s. "Bidesh" is used and idealized to contrast with the poverty and insecurity of life (Zeitlyn, 2013). Carrying a conception that "Bideshi" (who lives in Bidesh) people are rich enough, secure enough, and what Gardner (1993) shows that it gives political power also. There is a concept of "Bideshi Badi" (someone who lives outside the country for earning money and who has enough property from a particular house). "Londoni Badi" (someone lives in London from that house), "Italy Badi" (someone lives in Italy from that house), or "Japani Badi" (someone lives in Japan from that house), are the common terminologies to refer to a powerful house (in the sense of wealth).

After the Covid-19 attack returnees are hiding their identity as "Bideshi" or "Bidesh Ferot", therefore the government is unable to trace them when it is needed (Manabzamin, 2020). So, the so-called "Bideshi Badi" or "Londoni Badi" or "Italy Badi" is not focusing on their pride rather migrants and their families are hiding this identity because of the common stigma that "Bideshi" people are the carrier of the corona virus. Researchers try to reveal the question of how the pandemic is connected to the 'migrants'. Is there any politics of stigmatization? Is this social stigma making a class distinction? Is it going to affect the upcoming expatriate's life? Are we demoralizing and decreasing remittance unconsciously? Is it going to be a massive aftershock socially and economically? Therefore, reconsidering the Covid-19 pandemic and expatriate life will be discussed in academia to get a better future. Accepting the expatriates without stigma might bring forth golden days and create a class-neutral society. Without analyzing the current situation, we will not be able to set our vision, impeding our growth. Policymakers might think about it.

Objectives of the Study: The explicit aims of this paper intend to excavate -

- To unfold the anti-expatriates sentiments after the Covid-19 pandemic

- Challenges amidst in the migration sector

- Stigmatization by authority and society

- Migrant's socio-economic inclusion and social cohesion.

\section{Related Literature}

Karim, Islam \& Talukder (2020) mentioned in their paper- "Travellers as well as returning migrant workers and their relatives coming from China, Italy, and the Middle East are believed to be the original bearers of the coronavirus to Bangladesh, and it has since spread throughout the country. With the increase of incidents of COVID-19 around the world as well as in Bangladesh, commercial flights have been limited in and outside the country. As a result, an immense number of migrant workers are trapped, affected, and in dire circumstances". However, they did not explain the reasons and consequences of this circumstance. How migrants are being classified as 'others' is a matter of concern. Researchers tried to excavate the reasons to be believed as 'the original bearers'. Besides, the impact of such belief (the original bearers) has dire significance. Sorker (2020) in a featured article of 'Migration Policy Institute' stated simply- "When they return to Bangladesh they are isolated socially, and ostracized by neighbors who fear they are COVID-19 carriers". He mentioned the economic loss and the households' dependency on remittances have unexpectedly been confronted.

With ruthless snags meeting their foodstuff, wellbeing, education, and housing costs. Moreover, movements of migrants have the social, economic, and cultural dynamics of shaping. Communities and societies of all around the world, accounting (or not) for migrants recovery and response efforts will affect the crisis' trajectories in COVID- 19. Inclusive public health efforts will be crucial to effectively contain, and mitigate the outbreak, reduce the overall number of people affected, and shorten the emergency (Berger et al., 2020). Due to restrictions of mobility, many migrants in the host country have been left standard of living, food, and shelter uncertain, and also lost the ability to return home. While they've returned to their home country, they had to face xenophobia and discrimination, and have been accused of spreading the COVID-19. Meanwhile, governments have no tangible program to support (simplifying visa application, renewal, and visa 
overstaying and waiving fees) to the returnee migrants. Widespread hate speech triggered them unwilling to take health care services like testing and screening for COVID-19.

More generally, the COVID-19 pandemic has been weaponized to proliferate anti-migrant narratives, and call for amplified immigration control, and reduction of migrants' human rights (Banulescu-Bogdan et al., 2020). The other three international organizations published reports on the impact of Covid-19 on migrants. Guadagno (2020) in Migration Research Series $\mathrm{N}^{\circ} 60$ International Organization for Migration (IOM) analyzes diversity measures of migrants adopted by host and home country to mitigate its negative impacts (IOM, 2020). In the publication of UN Economic and Social Commission for Western Asia - by ESCWA, UNICEF Regional Office for South Asia discussed migrants and refugees; this publication focuses on income security, education, and health issues of migrants. It also discussed trafficking in the pandemic, return, and voluntary repatriation (ILO, 2020). UNICEF Regional Office for South Asia reported the vulnerability of migrant workers and the impact of COVID-19 in the South Asia perspective on the discourse of labor migration. It also outlined recommendations for the private sectors to support migrant workers impacted by the COVID-19 pandemic (UNICEF, 2021). Socio-cultural impact and individual suffering of migrants in the COVID-19 outbreak have been ignored mostly by the governments and non-governmental actors in South Asia. However, most of the reports and researches are on economic loss or social loss. Therefore, in this paper, we tried to explore the anti-expatriates sentiments, challenges, social cohesion, and stigmatization by analyzing people's reactions to returnee migrants which are ignored in other research and reports.

\section{Methodology}

This paper is exclusively concerning the returnee migrants after the breakout of Covid-19. Researchers have decided to collect data from the selected spot in Bangladesh, which was the corona's hotspot of Bangladesh. Both primary and secondary data were used in this study. While collecting primary data- A total of 58 indepth telephonic interviews and video group discussions (Zoom, Skype, Google Meets) was taken to explore valid and reliable data; where 49 were realized, and the remaining 9 were discarded due to non-cooperation of respondents. The secondary data, used in this research, were collected from scholarly journals research papers, newspaper articles, and social media posts. To collect the qualitative data, researchers used a purposive sampling method without following any structured questionnaire. At the beginning of each interview, the researcher introduced the research objective to the respondents. When required twice or thrice, interviews were arranged with a single person to achieve reliable information. Due to the social distancing guideline of WHO (World Health Organization), researchers also used shadow observation and ethnography processes (Kozinets, 2006). Among the returnee expatriates (interviewees), 11 were from the country K.S.A, 6 were from U.A.E, 4 were from Qatar, 17 were from the EU (Italy, U.K, Germany \& France), 8 were from the U.S.A, and 3 were from Canada. There were 33 male respondents and 16 female respondents. Alongside, 27 respondents' educational qualifications were below Higher Secondary School (H.S.C), 18 respondents' completed Graduation (Honor's), and 4 respondents' were above Graduation/Post Graduation.

\section{Findings}

Who is the Carrier: To begin the discussion here, first of all, we have to identify who a migrant is? Internationally it is recognized "a migrant as any person who is moving or has moved across an international border or within a State away from his/her habitual place of residence, regardless of (1) the person's legal status; (2) whether the movement is voluntary or involuntary; (3) what the causes for the movement are; or (4) what the length of the stay is (The UN Migration Agency (IOM)). According to this short term or long term, businessman or worker, illiterate or literate, male or female, old or young, legal or illegal, permanent or temporary, forced or deliberate all are equally treated as a migrant. Bureau of Manpower, Employment, and Training (BMET) express that- within 2018-2019 more than 1.3 million workers migrated from Bangladesh. Here, the legal migrated workers are counted. The most important thing is that they count workers only.

Meanwhile, there are so many people migrated from here, not as a worker. For instance, every year a large number of students go abroad for higher studies, and they usually stay at least 2 to 6 years (U.S. Embassy in Bangladesh, 2019). To fulfil labor shortages, Bangladeshis, particularly from the Sylhet region, went to the United Kingdom just after the Second World War, which initiated chain migration of further workers and 
family members to the UK in the 1950s, 1960s, and 1970s; therefore, after 50-60 years they are permanently out migrated (van Schendel, 2009, Zeitlyn, 2013). Though they settled down abroad, they have connections to Bangladesh. Even they feel Bangladesh is their "Desh" (Zeitlyn, 2013). According to the National Population and Housing Census-2011, between 2006 and 2011, 3.5 million had left the nation. However, the survey shows that 95 percent of migrants are still considered "household members" and not "emigrants". [BBS (2012), p. 19, p. 322.]. It is easy to say that they feel comfortable in their homeland, which is evident after the break of this pandemic. Whenever they see that long-distance staying is making loneliness and at the same time influences their immunity by breaking down the emotional strength, they try to come back to their 'household members'. However, the irony is that whenever they wanted to come back, the people of the host country did not receive them cordially. Rather people stigmatized them by spreading hate speech. The hokum is that in the meantime so many people entered into the country, but the so-called "Probashi"s are convicted for spreading out the virus. For example, every year a number of people visit Bangladesh as a tourist (Tourism Statistics, 2021). Not only this, almost half a million passengers have been screened in all the ports across the country only from 21st January to 8th March (Health Bulletin, DGHS). Among them, various people are included (Govt. Officials, Tourist, Foreign Worker, "Probashi", Students, and so on.). The first case was identified on 8th March; before that, a group of people was carried from China by the ministry of foreign affairs, and after maintaining quarantine procedure they were sent back to their friends and family members.

Unfortunately after all these things are happening who can say that who is the carrier? Here, convicted "Probashi"s is not student, govt. official or a tourist; even not a permanently migrated wealthy businessman of London. The so-called illiterate, workers, lower-class people got the accusation for this situation after getting viral of a video. All are migrants, but we just noticed the Middle East workers or 'Italian Imbeciles'. Are we sure about this? No one can say the right answer.

Contested Narrative of "Probashi": The very term "Bidesh" is related to another term "Probashi" which is translated from the word "Migrant". Katy Gardner (1993) comprises the term "Bidesh" with that it is connected with the 'foreign countries' and as well as it refers to the 'source of the economy.' ${ }^{[6]}$ Simultaneously, the word "Probashi" has a discourse that 'someone who lives in foreign countries to earn money. Whenever someone fills up a form in Bangladesh where he/she has to fill up father or mother's occupation, there is an option "Probashi". That means the person who lives in a foreign country to earn money. If anyone who studies in a foreign country for six to eight years is not identified as "Probashi". Though the latter one writes fairy novels of his life as "probash jibon" (life of emigrant) or though they are living outside of the country, they are not designated in the same way. Therefore, the term "Probashi" has a different discourse. Think about a government service holder who has been living in a foreign country that is not identified under this term. The term is related to the uneducated, worker class living outside for economic security (Zeitlyn, 2013). Indeed, here the term "Bidesh Ferot" does not mean an educated person.

In Bengali, the very word "Bidesh Ferot" means "bidesh theke asha" which is someone who returned from outside of the motherland. However, the pandemic situation reminds us that the word is not so easy to explain as it is. "Probashi'ra jokhon deshe asha shuru korlo tokhon corona akranto howa shuru holo" (Whenever those "Probashi"s came back to the country then people were being affected by corona). It is crucial to look at the connotation of the sentence. Here, no one identifies those people who are educated. Instead, it refers to those who are uneducated, lower-class workers, the odd-job holder, who lives outside only for money. After all, Covid-19 excavates the new scenario of the concept related to "Bidesh", "Probashi", "Bideshi Badi". Some other concepts, for instance, "Shami Bidesh" (someone whose husband lives outside) and "Bideshi Jamai" (a husband who lives outside the country) are very common and highly connected to this pandemic situation. Both terms have positive and negative connotation which has an impact on society, for example, the word "Remittance Fighter" by which "Probashi" or "Bideshi" people are trying to fight against the stigma and to retain their social, cultural capital. All these concepts related to 'Bidesh' will exceedingly influence the aftershock of the pandemic.

Hate towards Expatriates: The expatriates' have been persecuted mostly in this time of the Covid-19 outbreak. We have observed anti-expatriates sentiments in social media, the governments, and also the citizens are spreading the rumor that - expatriates are only responsible for bringing the coronavirus. As a result returnee expatriates are being physically assaulted and humiliated by neighbors and society in 
different parts of Bangladesh. We observed that banners were put up in the tea stall, shop, etc. mentioning the ban of the entrance of expatriates. Even though, some hospitals noticed "No patients or visitors returning from abroad will come to this hospital". Expatriates Welfare and Overseas Employment Ministry have not taken any step to protect the humanitarian behavior of the overseas returnee. For a good reason, expatriates are said to be the main driving force of the country's economy. Bangladeshi expatriates sent a record remittance of $\$ 16.4$ billion in the concluded fiscal year FY 2018-2019 (Dhaka tribune, 2020). On top of that, the government officially stigmatized the expatriates with quarantine seals in their hands and flying red flags at their homes. The mobile court fined some expatriates for ignoring the mandatory home quarantine of 14 days after they arrived from abroad.

In this way, with the state's help, hate crime spread out against the expatriates and their families. The law enforcement agency has identified expatriates as socially unacceptable people and spreaders of the coronavirus. As a result, there have been incidents of trolls and diatribe of expatriates on social media. In social media, people advised expatriates not to back to Bangladesh. "Expatriates, you have gone abroad for a better life. Please... stay abroad. When you come back to the country, you will kill your family and also will kill us too". Returning from abroad, those who used to be hugged by their neighbors and relatives are now being avoided. They never thought they would be neglected in such a way in their homeland. This is how an expatriate expressed his frustration- "While I was living abroad, everyone used to ask- when will I come back to the country? Now, I'm in my native country, but nobody knows except my family".

Paradoxical Narrative of Immigrants: An identity crisis emerged in Bangladesh after the Covid-19 pandemic for the Bangladeshi migrants and expatriates in their homeland. They are being solely blamed for bringing coronavirus rather than the administrative failure of the government to take precautionary measures. Before the Covid-19 pandemic, they were treated as remittance fighters. The controversial identity of belonging and not belonging to Bangladesh has raised a challenging narrative. In fact, we are cursing to whom? The labor expatriate from the Middle East or educated migrants of so-called developed countries? The discourse of "Probashi" has multiple dimensions. In society, hate speech triggered the returnee expatriates from the Middle East; those commonly treated as uneducated labor in the airport and society. Electronic and social media played an anti-migrant psyche which resulted in physical assaults and extortion. However, no one blamed returnee expatriates from U.S.A, U.K., and European Union. Here is a class distinction between educated expatriates and uneducated expatriates. According to wage earner remittance inflows of Bangladesh Bank until February 2020 (2019-2020 FY) remittance received from Middle-East (Bahrain, Kuwait, Oman, Qatar, K.S.A., U.A.E. Libya, and Iran) was USD 7172.70 million whereas total remittance inflows were USD 12498.56 million (Bangladesh Bank,2020). Interestingly, uneducated expatriates have the highest contribution to the remittance of the economy. Contrary, Bangladeshi expatriates living in the U.S.A, Canada, U.K., and European Union have received the highest education level from their homeland and become expatriates to obtain higher study or skilled professionals.

They have no significant contribution to the Bangladesh economy. Renowned educationist and founder of "Bishwa Sahityo Kendro"Professor Abdullah Abu Syeed express his opinion in an interview with "Voice of America, Bangla" about those skilled professionals of Bangladesh living abroad (VoA, 2020). "If educated expatriates send 3\% of their total income to the country as remittance, it may be more than the current total remittance. They may send this money to their family members or as an investment to the country or philanthropy. It's a question of morality and payback of debt to their homeland as if they have grown up \& received education from public tax. Unfortunately, most educated and highly paid professionals (not all of them) bring to an end all connections after became emigrants. This is a kind of betrayal and injustice to their motherland". Following this comment, Professor Abdullah Abu Syeed was brutally assaulted and trolled on social media by the Bangladeshi origin professionals in America and Europe. They feel offended by his comment. However, it was a bitter truth that has never been said before. As a strategy to secure the unpredictable future of their motherland, skilled professionals try to acquire migration opportunities to the developed country as a way of controlling citizenship rights and economic opportunities for their next generation. Therefore, they even sold all assets of the country and took the money abroad. When society was slanging to the "Probashi", this segment of expatriates was out of range and returnees of the Middle East were being humiliated. Thus, the discourse of "Probashi" has been diversified to portray the class distinction in contemporary Bangladesh ranging from economies to culture and media perception. 
Authoritarian Stigma: Along with social stigma, authority paves the way to be stigmatized. After returning to their community, migrants faced a challenge to cope up with their "Desh". Their long-cherished dream gets stumble. Authority hoisted the red flag on returnee migrants' residences. Though, the initiative was for protecting others from being infected. Unfortunately, these red flags are not protecting others even they are making the worst situation for migrants; especially for 'lower class', 'illiterate', 'middle east workers' by spreading out a message to mass people that- they are harmful, infected, should be avoided socially which binds the returnee to become psychologically stressed and to violate the rules of quarantine. The fact is that in most of the cases, the so-called successful people who returned to their homes did not get this type of reception. In most cases without ensuring essential services local authorities rambunctiously hoisted flags on so-called unconscious migrants. Hoisting a flag is not the problem instead of creating class differences, and humiliating social capital is a significant concern. People treated these houses like a criminal's house due to the presence of police and other authoritarians covered by white PPE.

\section{Conclusion and Limitations}

Limitations of the Study: First of all, the methodological limitation of long participant observation is replaced by netnography. Here, researchers were not able to maintain all the aspects of qualitative research. Secondly, researchers considered the limitations of not going to any migrants physically/offline. At the same time, face-to-face interviews were avoided due to personal protection or social distancing. However, the individual network was used to reach the respondents.

Concluding Remarks: During the Covid-19 pandemic, social media has played a vital role to spread hate speech towards returnee migrants. Civil society and social activists were silent and did not play any proactive role to mobilize kinder discourse and demonstrate solidarity against the anxiety and hate of immigrants. After the emergence of the Covid-19 pandemic, Bangladesh started experiencing a fall of remittance where the economy is highly dependent on the cash flow of remittance. However, policymakers should rethink the migrant workers in the functioning of state economies. This pandemic is an unprecedented emergency that demands an exceptional comprehensive response. Amidst the critical situations, the government should introduce migrant's friendly policies and regulations to improve security \& protection, file complaints, receive justice, or compensations by establishing bilateral/ multilateral agreements with destination countries. It is challenging to ensure the wellbeing and protection of migrant rights by developing countries like Bangladesh, where the economy and health system have succumbed to the Covid-19 pandemic. Along with returnee migrants and a large group of Diasporas worldwide are in severe anxiety during this pandemic situation. Returnee migrants have experienced physical assaults and discrimination in assessing medical facilities.

Most of the countries have imposed border closures to control the spread of Covid-19. Returnee migrants have no hope of ray to go back to their previous work although few countries are revoking economic activities. The immigrant Diasporas were facing the threat of job losses and deportation measures resulting from draconian immigrant policies. On the other hand, they experienced xenophobic sentiment by the administration and their society due to stigmatization. Thus, the new rhetoric of migration will have longterm effects on social inclusion. After the Covid-19 pandemic, stigmatization and excluding returnee migrants resulted in higher contamination as they hide the potential symptoms rather than seeking treatment. Governments' should declare extra incentives if it wants to keep remittance flow buoyant. Due to a negative mindset about returnee migrants, some financial institutions and banks halt the service of "Expatriate Advisory/Help Desk". There were no strict guidelines against this disruption of service. Ministry of Expatriates' Welfare and Overseas Employment, Bangladesh should generate a central database with the help of civil aviation and immigration departments for the surveillance of returnee migrants who returned after the COVID-19 outbreak. 


\section{References}

Bangladeshi Students Studying in United States Reach All-Time High | U.S. Embassy in Bangladesh. (2019). Retrieved 31 July 2021, from https://bd.usembassy.gov/bangladeshi-students-studying-in-unitedstates-reach-all-time-high/

Bangladesh Bureau of Statistics. (2012). Retrieved 28 March 2021, from https://www.amazon.com/Statistical-Yearbook-Bangladesh-2012-32nd/dp/9849005599

Bangladesh | Tourism Statistics | CEIC. (2021). Retrieved 31 July 2021, from https://www.ceicdata.com/en/bangladesh/tourism-statistics?fbclid=IwAR1f6qq7KC64g20fU1pA1dJ IcKMcy5bFxKt9tBGCnSyah6Phh54m3VgOrR0

Banulescu-Bogdan, N., Benton, M. \& Fratzke, S. (2020). Coronavirus is spreading across Borders, But It Is Not a Migration Problem. Retrieved 30 July 2021, from https://www.migrationpolicy.org/news/coronavirus-not-a-migration-problem

Berger, Z., Evans, N., Phelan, A. \& Silverman, R. (2020). Covid-19: control measures must be equitable and inclusive. BMJ, m1141.

Country-Wise Inward Remittances. (2020). Retrieved 15 April 2021, from https://www.bb.org.bd/econdata/wagermidtl.php.

COVID-19 and Migration for Work in South Asia. (2021). Retrieved 28 July 2021, from https://www.unicef.org/rosa/reports/covid-19-and-migration-work-south-asia.

DGHS Health Bulletin. (2020). Retrieved 28 April 2021, from https://dghs.gov.bd/index.php/en/publications/health-bulletin/dghs-health-bulletin

Gardner, K. (1993). Desh-Bidesh: Sylheti Images of Home and Away. Man, 28(1), 1.

Guadagno, L. (2020). Migrants and the COVID-19 pandemic: An initial analysis | Environmental Migration Portal. Retrieved 28 July 2021, from https://environmentalmigration.iom.int/migrants-and-covid19-pandemic-initial-analysis

Hasan, S. (2020). Remittance Inflow: Eid may tick it up this month. Retrieved 19 April 2021, from https://www.thedailystar.net/frontpage/news/remittance-inflow-eid-may-tick-it-month-1903336

Impact of COVID-19 on Migrants and Refugees in the Arab Region - Technical Paper. (2020). Retrieved 28 July 2021, from https://www.ilo.org/beirut/publications/WCMS_764756/lang--en/index.htm.

Impacts of COVID-19 on Migrant Workers and Remittance / daily sun. (2020). Retrieved 18 April 2021, from https://www.daily-sun.com/post/483443/Impacts-of-COVID19-on-Migrant-Workers-andRemittance

Karim, M., Islam, M. \& Talukder, B. (2020). COVID-19's impacts on migrant workers from Bangladesh: In search of policy intervention. World Development, 136, 105123.

Kozinets, R. (2006). Click to Connect: Netnography and Tribal Advertising. Journal of Advertising Research, 46(3), 279-288.

বিদেশ ফেরত কোয়ারেন্টিন অমান্যকারীদের বিরুদ্ধে ব্যবস্থা :পুলিশ. (2020). (Action against Quarantine Violators Returning Abroad: Police) Retrieved 18 April 2020, from https://www.mzamin.com/article.php?mzamin=218970\&cat=43/\%E0\%A6\%AC\%E0\%A6\%BF\%E0 \%A6\%A6\%Е0\%A7\%87\%Е0\%A6\%B6-\%Е0\%A6\%AB\%E0\%A7\%87\%Е0\%A6\% B0\%Е0\%A6\%A4$\%$ Е0\% $\%$ \%95\%Е0\%A7\%8B\%Е0\%A7\%9F\%E0\%A6\%BE\%

E0\%A6\%B0\%E0\%A7\%87\%E0\%A6\%A8\%E0\%A7\%8D\%E0\%A6\%9F\%E0\%A6\%BF\%E0\%A6\%A8\%Е0\%A6\%85\%Е0\%A6\%AE\%Е0\%A6\%BE\%E0\%A6\%A8\%E0\%A7\%8D\% E0\%A6\%AF\%E0\%A6\%95\%Е0\%A6\%BE\%Е0\%A6\%B0\%Е0\%A7\%80\%Е0\%A6\%A6\%Е0\%A7\%87\% Е0\%А6\%В0-\%Е0\%A6\%AC\%Е0\%A6\%BF\%Е0\%A6\%B0\%Е0\%A7\%81\%Е0\% А6\%A6\%Е0\%A7\%8D\%Е0\%A6\%A7\%Е0\%A7\%87-\%Е0\%A6\%AC\%Е0\%A7\%8D\% E0\%A6\%AF\%E0\%A6\%AC\%E0\%A6\%B8\%E0\%A7\%8D\%E0\%A6\%A5\%E0\%A6\%BE:\%Е0\%A6\%AA\%E0\%A7\%81\%Е0\%A6\%B2\%Е0\%A6\%BF\%E0\%A6\%B6.

করোনাভাইরাস : ফেরত আসা প্রবাসীদের বড়অংশ পর্যবেক্ষণের বাইরে-BBC News বাংলা . (2020). (Coronavirus: Large part of returning expatriates out of observation - BBC News Bangla) Retrieved 18 April 2021, from https://www.bbc.com/bengali/news-51858495

Remittance hits record $\$ 16.4 \mathrm{~b}$ in FY19. (2020). Retrieved 15 April 2021, from https://www.dhakatribune.com/business/economy/2019/07/03/remittance-hits-record-16-4b-infy19. 


\section{Journal of Social and Development Sciences (ISSN 2221-1152)}

Vol. 12, No. 2, pp. 27-34, June 2021

Schendel, W. (2009). A history of Bangladesh. Cambridge University Press. DOI: 10.1017/CB09780511997419.

Sorkar, M. (2020). COVID-19 Pandemic Profoundly Affects Bangladeshi Workers Abroad with Consequences for Origin Communities. Retrieved 28 July 2021, from https://www.migrationpolicy.org/article/covid-19-pandemic-profoundly-affects-bangladeshiworkers-abroad-consequences-origin

VoA Bangla. (2020). Retrieved 15 April 2021, from https://www.youtube.com/watch?v=njHSCWb0TFE

World Bank Annual Report. (2017). Washington, D.C.: World Bank Group Document Detail. (2021). Retrieved 28 March 2021, from http://documents.worldbank.org/curated/en/143021506909711004/WorldBank-Annual-Report-2017.

Zeitlyn, B. (2013). Desh bidesh revisited. Identities, 20(3), 253-269.

Declarations: Ethics approval and consent to participate: Not Applicable

Availability of Data and Materials: All data generated or analyzed during this study are included in this article.

Competing Interests: No competing interests

Funding: Not Applicable

Authors' Contributions: Both authors have done it as per their expertise.

Acknowledgment: Not Applicable 